\title{
Peningkatan Kekakuan Sudu Turbin Angin Vertikal Berbahan Komposit Serat Karbon Melalui Rekayasa Penampang Inersia
}

\author{
Marsono, Ali, Alek P. Sembiring \\ Jurusan Teknik Mesin, Itenas, Bandung \\ Email:msn.a.kasa@gmail.com
}

\begin{abstract}
ABSTRAK
Perubahan bentuk dan dimensi sudu akan menurunkan kinerja turbin angin. Perubahan bentuk dan dimensi sudu sangat dipengaruhi oleh kekakuan dan kekuatan sudu turbin tersebut. Pada kasus di lapangan, ditemui bahwa sudu turbin angin sumbu vertikal yang dibuat dengan bahan komposit serat karbon ternyata tidak memiliki kekakuan yang baik jika hanya dibuat dengan satu lapis (layer) serat karbon. Untuk mengatasi masalah kekakuan ini, maka dilakukan penambahan tulang penguat (stiffener rib) dari bahan yang sama pada sudu turbin angin. Pengujian yang telah dilakukan menunjukan bahwa penambahan tulang penguat pada sudu turbin angin sumbu vertikal telah menambah kekakuan sudu secara signifikan yang cenderung mengikuti grafik eksponensial. Kekakuan (K) sudu dengan tinggi tulang $6 \mathrm{~mm}$ adalah 0,0258 $\mathrm{kg} / \mathrm{mm}$. Kekakuan sudu dengan tinggi tulang $9 \mathrm{~mm}$ adalah 0,0740 kg/mm. Kekakuan sudu dengan tinggi tulang $12 \mathrm{~mm}$ adalah 0,2250 kg/mm. Di sisi lain, kekuatan lentur sudu turbin juga meningkat. Dengan penambahan tulang 6mm, kekuatan lentur maksimum ( max) mencapai 4,008 $\mathrm{kg} / \mathrm{mm}^{2}$, dengan penambahan tulang $9 \mathrm{~mm}$ kekuatan lentur mencapai $4,145 \mathrm{~kg} / \mathrm{mm}^{2}$, dengan penambahan tulang $12 \mathrm{~mm}$ kekuatan lentur mencapai 4,544 kg/ $\mathrm{mm}^{2}$.
\end{abstract}

Kata kunci: sudu turbin angin sumbu vertikal, inersia penampang, kekakuan, kekuatan lentur.

\begin{abstract}
Changes in shape and dimension of the blade will decrease the wind turbine performance. These change are strongly influenced by the stiffness and strength of turbine blade. It was found that vertical axis wind turbine blades which is made with carbon fiber composite did not have good stiffness if it was made with only one layer of carbon fiber. To overcome this stiffness problem, stiffener rib with the same material was applied on wind turbine blade. The test that has been done shows that the addition of the stifferner rib to the vertical axis wind turbine blade has significantly increased the stiffness that tends to follow the exponential graphic. The stiffness $(K)$ of the blade with $6 \mathrm{~mm}$ rib height is $0.0258 \mathrm{~kg} / \mathrm{mm}$. The blade stiffness with $9 \mathrm{~mm}$ rib height is $0.0740 \mathrm{~kg} / \mathrm{mm}$. The blade stiffness with $12 \mathrm{~mm}$ rib height is 0.2250 $\mathrm{kg} / \mathrm{mm}$. On the other hand, the bending strength of the turbine blade is also increased. With the addition of $6 \mathrm{~mm}$ rib, the maximum flexurall strength $\left(\sigma_{\text {max }}\right)$ reaches $4,008 \mathrm{~kg} / \mathrm{mm}^{2}$. With the addition of $9 \mathrm{~mm}$ rib, the strength reaches $4,145 \mathrm{~kg} / \mathrm{mm}^{2}$. With the addition of $12 \mathrm{~mm}$ rib, the strength reaches $4,544 \mathrm{~kg} / \mathrm{mm}^{2}$.
\end{abstract}

Keywords: vertical axis wind turbine, inertia, stiffness, flexurall strength. 


\section{PENDAHULUAN}

Turbin atau kincir angin adalah sebuah alat yang berfungsi untuk mengubah energi angin menjadi energi mekanik. Energi mekanik yang dihasilkan dari turbin ini dapat dimanfaatkan untuk membangkitkan tenaga listrik, ataupun dimanfaatkan untuk menggerakkan peralatan mekanis laininya. Angin adalah sumber energi terbarukan dan merupakan salah satu pilihan energi alternatif yang baik untuk menggantikan energi fosil. Pemanfaatan tenaga angin dapat membantu mengurangi emisi karbondioksida dan emisi sulfur-dioksida akibat dari pembakaran bahan bakar fosil yang berdampak terhadap perubahan lingkungan global (Jagadish et.al., 2016) Angin dapat menggerakkan turbin tanpa harus membayar sehingga tidak terkena dampak fluktuasi harga bahan bakar fosil. Tenaga ini juga tidak perlu ditambang, digali dan dipindahkan ke lokasi pembangkit listrik.

Sebagai negara kepulauan, Indonesia memiliki garis pantai yang sangat panjang. Kondisi geografis ini menjadi sebuah keuntungan, karena pantai adalah daerah yang memiliki potensi sumber daya angin yang besar dan dapat dimanfaatkan sebagai penggerak turbin. Dalam rangka pengembangan pemanfaatan sumber daya angin di indonesia, telah banyak dilakukan penelitian tentang turbin angin sumbu vertikal yang cocok untuk kecepatan rata-rata angin di perairan Indonesia, yaitu berada di kisaran $4 \mathrm{~m} / \mathrm{s}-5 \mathrm{~m} / \mathrm{s}$ (Hero et.al, 2016).

Pada pembuatan sudu turbin angin sumbu vertikal dengan bahan komposit serat karbon, ditemui kasus dimana sudu turbin yang dibuat dengan 1 lapis (layer) serat karbon ternyata belum dapat memberikan kekakuan yang diinginkan. Kekakuan sudu yang rendah akan berdampak kepada perubahan bentuk dan dimensi sudu dan akan mengakibatkan penurunan kinerja turbin angin. Dalam penelitian ini akan dilakukan optimalisasi penggunaan serat karbon dalam pembuatan sudu turbin angin sumbu vertikal. Penghematan penggunaan serat karbon dilakukan dengan merekayasa bentuk penampang sudu turbin angin sedemikian hingga kekakuan sudu yang dipersyaratkan tetap dapat terpenuhi. Kekakuan sudu turbin dapat dicapai dengan menambahkan tulang (rusuk) penguat atau stiffener rib. Pengujian untuk mengetahui kekakuan sudu turbin angin dilakukan dengan pembebanan statik terhadap sudu turbin dengan tiga variasi ketinggian (ketebalan), yaitu $6 \mathrm{~mm}, 9 \mathrm{~mm}$ dan $12 \mathrm{~mm}$.

\section{METODOLOGI}

\subsection{Kekakuan dan Kekuatan Sudu Turbin Angin}

Sudu turbin angin dirancang sesuai dengan kondisi dan potensi sumber daya angin di suatu tempat tertentu. Setiap daerah yang memiliki kecepatan angin tertentu akan memiliki rancangan turbin angin yang berbeda dengan daerah lain. Satu hal yang sama dari semua rancangan turbin angin adalah bahwa bentuk dan dimensi sudu turbin angin tidak boleh berubah secara berlebihan akibat gaya dorong angin. Perubahan bentuk dan dimensi sudu turbin angin yang berlebihan akibat gaya dorong angin akan menurunkan kinerja turbin angin. Perubahan bentuk dan dimensi sudu akibat gaya dorong angin dapat diatasi dengan kekakuan (stiffness) dan kekuatan (strength) material. Di sisi lain, sudu turbin angin harus dibuat seringan mungkin. Sudu turbin angin yang ringan akan mereduksi kehilangan energi akibat dipakai untuk melawan gaya inersia yang timbul karena faktor berat sudu (Mohammed, 2013).

Sejak tahun 80-an, sudu turbin angin telah dibuat dari baja, aluminium, dan komposit dengan serat kayu, fiberglass, dan serat karbon. Sudu yang terbuat dari baja dan aluminium memiliki bobot yang lebih besar dan umur pakai yang relatif rendah dibanding komposit modern. Karena kekurangannya ini, sejak tahun 90-an hampir semua sudu turbin angin dibuat dari material komposit, terutama 
fiberglass. Serat karbon memberikan rasio kekuatan dan kekakuan tertinggi, namun memerlukan biaya yang tinggi (James L., 2000)

Kasus yang ditemui di lapangan adalah bahwa sudu turbin angin sumbu vertikal yang dibuat dengan bahan komposit yang disusun dengan satu lapis (layer) serat karbon dan resin ternyata tidak memiliki kekakuan yang baik. Dari percobaan-percobaan yang pernah dilakukan, untuk mendapatkan kekakuan yang cukup, dibutuhkan 3 sampai 4 lapis serat karbon yang dipadukan dengan resin. Penggunaan serat karbon dengan lapisan yang banyak akan membuat sudu tersebut menjadi lebih berat. Adapun bentuk sudu turbin angin sumbu vertikal yang akan dibuat terl 1 hat pada gambar 1

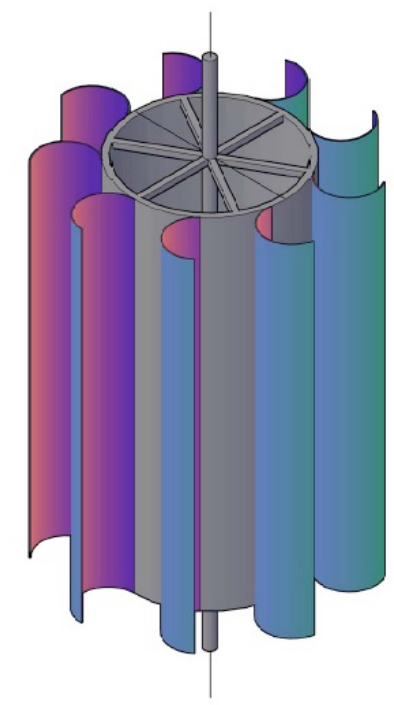

Gambar 1. Turbin angin sumbu vertikal yang akan dibuat

Pemahaman bahwa kekakuan dapat ditingkatkan dengan menambah luas penampang inersia dijadikan dasar dalam penelitian ini untuk membuat dan menguji sudu turbin angin sumbu vertikal dengan satu lapis serat karbon dan tambahan rusuk penguat dari bahan yang sama yaitu komposit serta karbon. Sudu turbin yang dibuat dengan satu lapis serat karbon dengan tambahan rusuk penguat diharapkan dapat mencapai kekakuan yang diinginkan sekaligus bisa mendapatkan berat sudu minimal.

\subsection{Rancangan Sudu Turbin Angin}

Sudu turbin angin sumbu vertikal yang dibuat dalam penelitian ini berbentuk setengah lingkaran, dengan dimensi radius $150 \mathrm{~mm}$ dan tinggi $250 \mathrm{~mm}$, sebagaimana terlihat pada gambar 2. Ketebalan sudu tidak ditentukan karena mengikuti ketebalan serat karbon yang digunakan dengan tambahan resin, tapi dapat diperkirakan bahwa ketebalan sudu tidak lebih dari $1 \mathrm{~mm}$. 


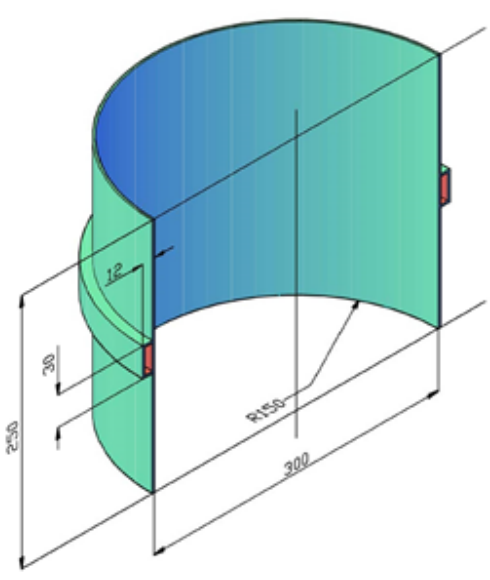

Gambar 2. Dimensi sudu

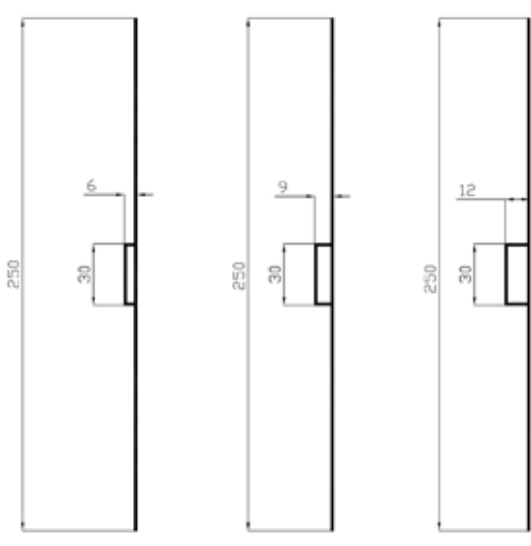

Gambar 3. Dimensi penampang dan tulang sudu

Sudu turbin angin diberi tambahan rusuk penguat dengan tiga variasi ketinggian (ketebalan), yaitu $6 \mathrm{~mm}, 9 \mathrm{~mm}$ dan $12 \mathrm{~mm}$. Lebar tulang penguat adalah $30 \mathrm{~mm}$. Gambar penampang sudu terlihat pada gambar 3. Tulang penguat sudu dibuat berongga untuk tetap mendapatkan berat minimal.

\subsection{Inersia Penampang Sudu turbin}

Inersia penampang $\left(\mathrm{I}_{\mathrm{xx}}\right)$ sudu turbin angin dengan penambahan rusuk penguat dapat dihitung secara teoritik. Inersia penampang sudu turbin angin dengan penambahan tulang dengan lebar tulang $30 \mathrm{~mm}$ dan tinggi tulang $6 \mathrm{~mm}$, sebagaimana terlihat pada gambar 4, dapat dihitung dengan beberapa langkah.

Perhitungan inersia untuk sudu dengan lebar tulang $30 \mathrm{~mm}$ dan tinggi tulang $6 \mathrm{~mm}$ diawali dengan penentuan titik berat dari penampang sudu. Titik berat penampang dapat dihitung dengan menghitung gabungan titik berat dari bidang-bidang pembentuk penampang secara proporsional. Penggabungan titik berat ini yang melibatkan luas penampang masing-masing bidang pembentuk penampang.

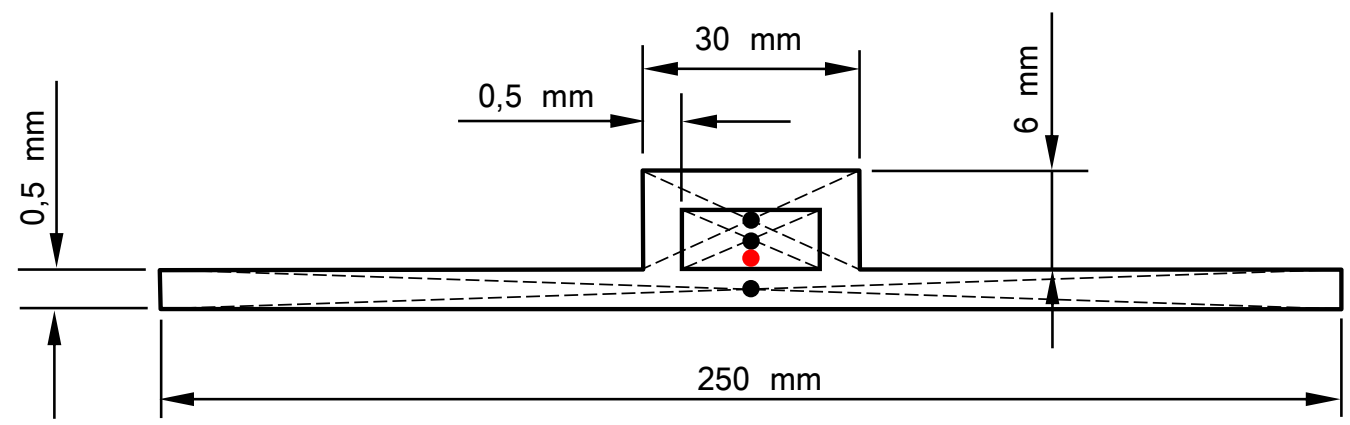

Gambar 4 dimensi penampang sudu dengan tinggi tulang $6 \mathrm{~mm}$

Masing-masing bidang pembentuk memiliki luas :

$$
\begin{aligned}
& A_{1}=250 \times 0,5=125 \mathrm{~mm}^{2} \\
& A_{2}=30 \times 6=180 \mathrm{~mm}^{2} \\
& A_{3}=29 \times 5,5=159,5 \mathrm{~mm}^{2}
\end{aligned}
$$


Posisi titik berat dihitung dengan rumus :

$$
\begin{aligned}
& \bar{x}=\frac{x_{1} A_{1}+x_{2} A_{2}-x_{g} A_{g}}{A_{1}+A_{2}+A_{g}}=\frac{(125 \times 125)+(125 \times 180)-(125 \times 159.5)}{125+180-159.5} \\
& \bar{x}=125 m m \\
& \bar{y}=\frac{y_{1} A_{1}+y_{2} A_{2}-y_{g} A_{g}}{A_{1}+A_{2}-A_{g}}=\frac{(0.25 \times 125)+(3.5 \times 180)-(3.25 \times 159.5)}{125+180-159.5} \\
& \bar{y}=1 \mathrm{~mm}
\end{aligned}
$$

Inersia sudu turbin angin dengan tambahan rusuk dengan lebar 30mm dan tinggi $6 \mathrm{~mm}$ adalah :

$$
\begin{aligned}
& I_{x x}=\left(\frac{1}{12} \cdot b_{1} h_{1}^{3}+A_{1} d_{1}^{2}\right)+\left(\frac{1}{12} \cdot b_{2} h_{2}^{3}+A_{2} d_{2}^{2}\right)-\left(\frac{1}{12} \cdot b_{2} h_{3}^{3}+A_{3}+d_{3}^{2}\right) \\
& I_{x x}=\left(\frac{1}{12}(250)\left(0.5^{3}\right)+(125)\left(0.75^{2}\right)\right)+\left(\frac{1}{12}(30)\left(6^{3}\right)+(180)\left(2^{2}\right)\right)-\left(\frac{1}{12}(29)\left(5.5^{3}\right)+(159.5)\left(1.75^{2}\right)\right) \\
& I_{x x}=442.91 m^{4}
\end{aligned}
$$

Dengan cara yang sama, dapat dihitung inersia penampang sudu dengan tambahan tulang penguat dengan tinggi tulang $9 \mathrm{~mm}$ dan $12 \mathrm{~mm}$. Perhitungan yang telah dilakukan memberikan hasil inersia penampang untuk penampang sudu dengan tinggi tulang $6 \mathrm{~mm}, 9 \mathrm{~mm}$ dan $12 \mathrm{~mm}$, yaitu seperti yang terlihat pada tabel 1

Tabel 1 Momen Inersia Penampang Sudu denga tinggi tulang $6 \mathrm{~mm}, 9 \mathrm{~mm}$ dan $12 \mathrm{~mm}$

\begin{tabular}{ccc}
\hline No & Tinggi tulang Sudu & Inersia penampang $\left(\mathbf{I}_{\mathbf{x x}}\right)$ \\
\hline 1 & $6 \mathrm{~mm}$ & $442.91 \mathrm{~mm}^{4}$ \\
\hline 2 & $9 \mathrm{~mm}$ & $1004.23 \mathrm{~mm}^{4}$ \\
\hline 3 & $12 \mathrm{~mm}$ & $2000.45 \mathrm{~mm}^{4}$ \\
\hline
\end{tabular}

\subsection{Spesifikasi bahan komposit}

Bahan yang digunakan untuk pembuatan sudu turbin angin terdiri dari serat karbon, resin SHCP (Unsaturated Polyester Resin) dan katalis. Gambar serat karbon terlihat pada gambar 5.a, resin SHCP terlihat pada gambar 5.b. dan katalis terlihat pada gambar 5.c.

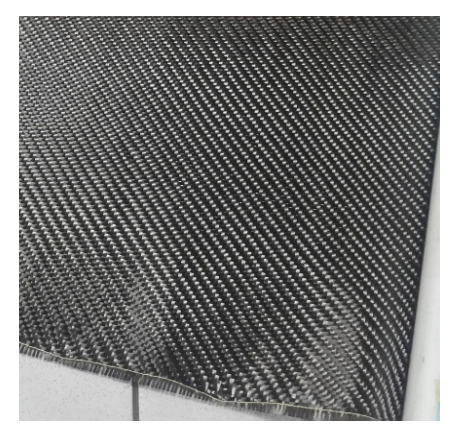

Gambar 5.a Serat karbon

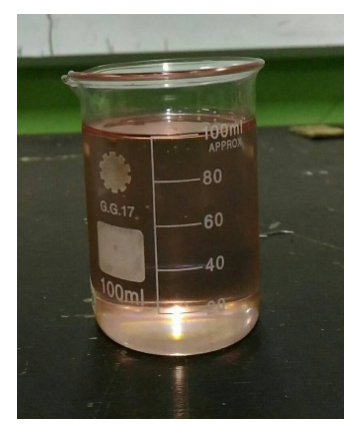

Gambar 5.b resin SHCP

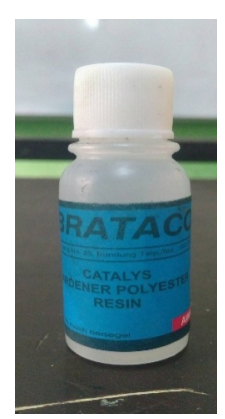

Gambar 5.c. katalis 


\subsection{Pembuatan Sudu}

Secara umum, pembuatan sudu turbin angin dilakukan dengan teknik Hand Lay Up, yaitu dengan menerapkan serat karbon pada cetakan terbuka dan dilapisi dengan resin SHCP yang telah dicampur dengan katalis. Pembuatan sudu diawali dengan pembuatan tulang penguat secara terpisah, seperti yang telihat pada gambar 6.a. Tahap selanjutnya adalah pembuatan sudu seperti yang terlihat pada gambar 6.b. Tahap terakhir adalah penyatuan tulang penguat pada sudu, seperti yang terlihat pada gambar 6.c.

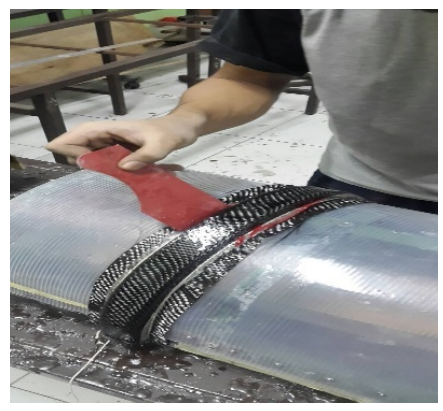

Gambar 6.a. pembuatan tulang penguat

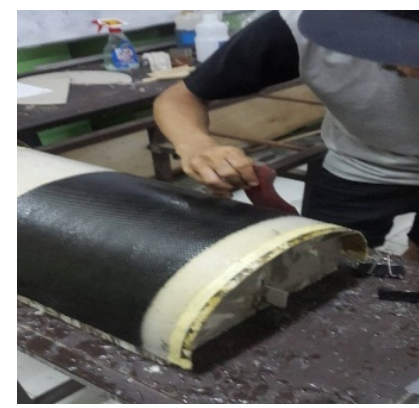

Gambar 6.b. pembuatan sudu turbin

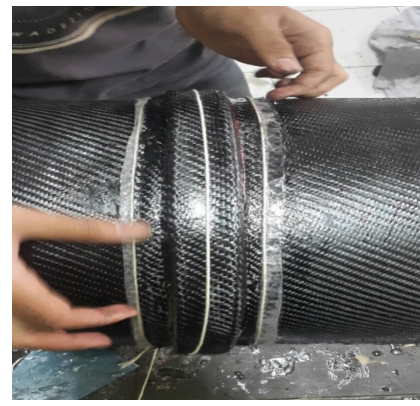

Gambar 6.c. penyatuan sudu dan tulang penguat

\subsection{Pengujian Sudu Turbin Angin sumbu vertikal}

Pengujian dilakukan untuk mengetahui karakteristik mekanik sudu turbin angin yang telah dibuat, terutama kekakuan sudu. Kekakuan yang tinggi akan membuat sudu turbin tidak berubah bentuk ketika mandapat beban dari tumbukan angin. Karakteristik mekanik lain yang juga ingin diketahui dari pengujian ini adalah batas kekuatan lentur dari sudu turbin angin tersebut. Pengujian untuk mendapatkan kedua sifat mekanik ini dilakukan dengan pembebanan statik.

Instalasi pengujian sudu dibuat sedemikian rupa mendekati fenomena pembebanan yang terjadi seseungguhnya pada sudu turbin, yaitu seperti yang terlihat pada gambar 7. Sudu turbin angin sumbu vertikal akan mendapatkan tumbukan angin dari arah belakang lengkugan radial dan akan mengaibatkan defleksi $(\delta)$ terbesar di bagian ujung sudu.

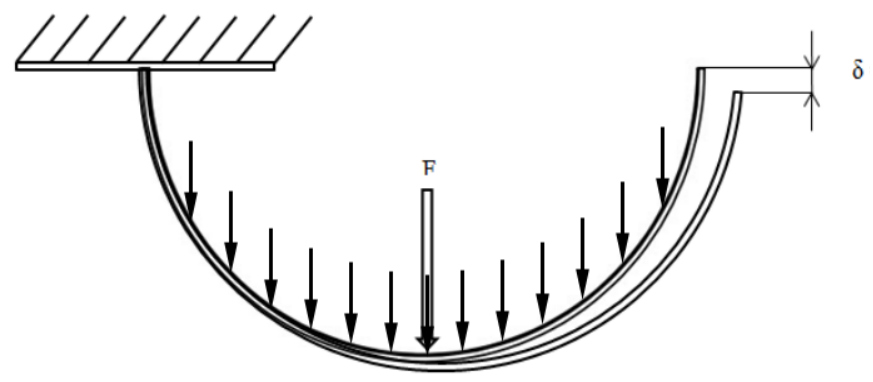

Gambar 7. Fenomena pembebanan pada sudu turbin angin sumbu vertikal dan defleksi pada sudu

\section{Standar Pengujian Sudu Turbin Angin sumbu vertikal}

Dari sumber-sumber referensi yang telah dipelajari, tidak ditemukan standar untuk pengujian sudu turbin angin sumbu vertikal. Adapun standar yang banyak digunakan di eropa adalah standar pengujian untuk turbin angin jenis sumbu horizontal, yaitu IEC - TS 61400-23 Wind turbine generator systems - Part 23: Full-scale structural testing of rotor blades. Salah satu karakteristik mekanis yang diuji pada turbin angin jenis sumbu horizontal adalah pengujian kekuatan statik (Static Strength Test), 
dengan beberapa metoda yaitu : metoda beban permukaan terdistribusi (Distributed surface loads), metoda pembebanan satu titik (Single-point method) dan metoda pembebanan banyak titik (Multiplepoint method) (Anonim, 2001).

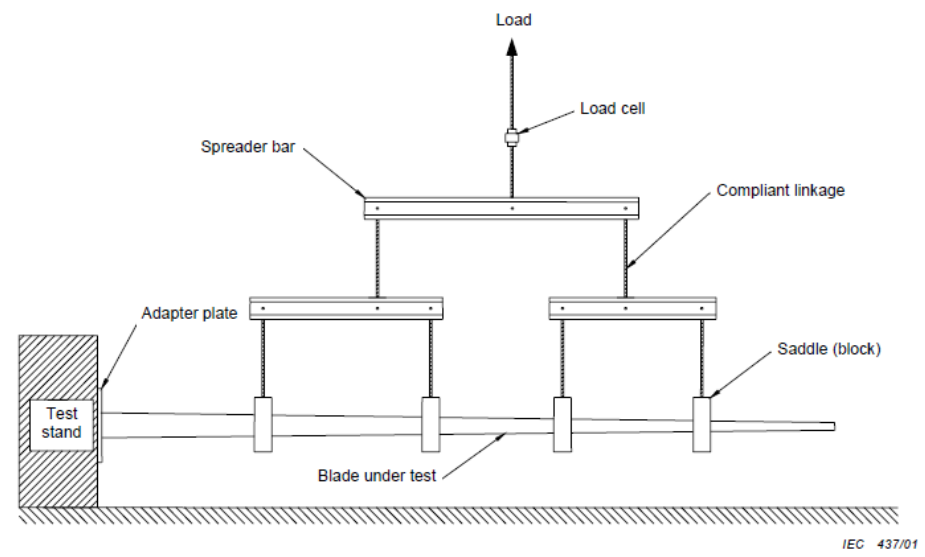

Gambar 8. Contoh instalasi pengujian sudu turbin angin sumbu horizontal (Anonim, 2001)

Salah satu contoh instalasi pengujian sudu turbin angin sumbu horizontal untuk mengetahui karakteristik mekanik terlihat pada gambar 8 yang memperlihatkan cara memberikan pembebanan di beberapa titik di sepanjang sudu turbin

\section{Skema pembebanan pada pengujian sudu turbin angin sumbu vertikal}

Dengan memperhatikan standar pengujian karakteristik mekanik pada sudu turbin angin sumbu horizontal IEC-TS 61400-23 maka dalam pengujian sudu turbin angin sumbu vertikal ini dilakukan metoda yang mirip dengan standard tersebut.

Sudu turbin angin sumbu vertikal memiliki luas penampang yang relatif besar, berbeda dengan penampang sudu turbin angin sumbu horizontal yang lebih ramping dan memanjang. Dengan pertimbangan tersebut maka sudu tubin angin sumbu vertikal ini akan diuji dengan pembebanan di banyak titik. Sudu turbin angin sumbu vertikal akan diberi beban dari arah belakang di 9 titik. Sembilan beban itu disatukan dengan rangka sehingga dapat ditarik dari arah depan pada satu titik. Skema pengujian dengan pembebanan di 9 titik terlihat pada Gambar 9.

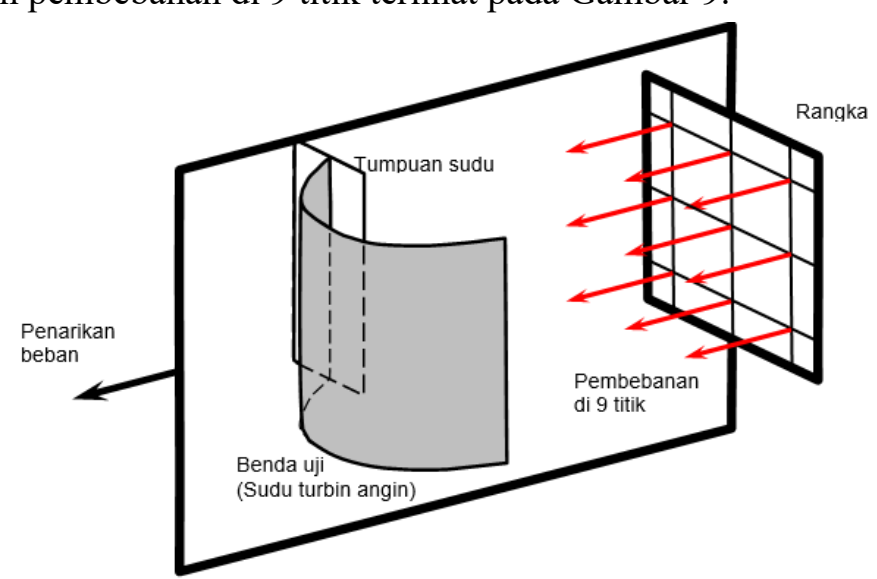

Gambar 9. Skema pembebanan pada pengujian sudu turbin angina sumbu vertikal

Besar tumbukan angin yang diterima oleh sudu sebanding dengan luas area bidang tumbukan dan kecepatan angin, atau dapat dituliskan dengan persamaan drag force:

Jurnal Itenas Rekayasa - 261 


$$
F_{D}=\frac{C d \times \rho \times V^{2} \times A}{2}
$$

Dimana

$$
\begin{array}{llll}
\mathrm{F}_{\mathrm{D}} & : \text { gaya drag }(\mathrm{N}) & \mathrm{V} & : \text { kecepatan angin }(\mathrm{m} / \mathrm{s}) \\
\mathrm{Cd} & : \text { koefisien drag } & \mathrm{A} & : \text { penampang sudu }\left(\mathrm{m}^{2}\right) \\
\rho & : \text { masa jenis media (udara/angin) }\left(\mathrm{kg} / \mathrm{m}^{3}\right)
\end{array}
$$

Dengan asumsi bahwa kecepatan angin yang mendorong sudu turbin angin adalah $5 \mathrm{~m} / \mathrm{s}$, maka secara teoritik tumbukan angin yang akan diterima oleh sudu turbin angin yang diuji adalah sebesar :

$$
\begin{aligned}
& F_{D}=\frac{C d \times \rho \times V^{2} \times A}{2}=\frac{2,3 \times 1,2 \times 5^{2} \times 0,075}{2} \\
& F_{D}=2,5875 \mathrm{~N}
\end{aligned}
$$

\subsection{Berat Sudu}

\section{HASIL DAN PEMBAHSAN}

Pengukuran berat bertujuan untuk mengetahui berat total spesimen sudu serta mengetahui berat masing-masing komponen pembentuk sudu, yaitu berat serat karbon dan berat resin. Pengukuran berat

\begin{tabular}{|c|c|c|c|c|c|c|c|}
\hline \multirow[t]{2}{*}{ No } & \multirow{2}{*}{$\begin{array}{l}\text { Tinggi tulang } \\
\text { sudu (mm) }\end{array}$} & \multirow{2}{*}{$\begin{array}{l}\text { No Benda Uji } \\
\text { (Sudu) }\end{array}$} & \multicolumn{3}{|c|}{$\begin{array}{l}\text { Berat } \\
\text { (g) }\end{array}$} & \multicolumn{2}{|c|}{$\begin{array}{c}\text { Perbandingan berat } \\
\text { serat \& resin }\end{array}$} \\
\hline & & & serat & resin & total & serat & resin \\
\hline 1 & $6 \mathrm{~mm}$ & Benda uji 1 & 33 & 84 & 117 & $28 \%$ & $72 \%$ \\
\hline 2 & & Benda uji 2 & 33 & 86 & 119 & $28 \%$ & $72 \%$ \\
\hline 3 & & Benda uji 3 & 33 & 94 & 127 & $26 \%$ & $74 \%$ \\
\hline 4 & $9 \mathrm{~mm}$ & Benda uji 1 & 34 & 90 & 124 & $27 \%$ & $73 \%$ \\
\hline 5 & & Benda uji 2 & 35 & 90 & 125 & $28 \%$ & $72 \%$ \\
\hline 6 & & Benda uji 3 & 34 & 92 & 126 & $28 \%$ & $72 \%$ \\
\hline 7 & $12 \mathrm{~mm}$ & Benda uji 1 & 36 & 89 & 125 & $29 \%$ & $71 \%$ \\
\hline 8 & & Benda uji 2 & 36 & 91 & 127 & $28 \%$ & $72 \%$ \\
\hline 9 & & Benda uji 3 & 35 & 93 & 128 & $27 \%$ & $73 \%$ \\
\hline
\end{tabular}
dilakukan pada bahan serat karbon sebelum dipadukan dengan resin. Setelah itu, berat sudu ditimbang kembali pada saat sudah selesai dikerjakan, yaitu pada saat resin sudah mengeras. Berat resin diketahui dengan cara mengurangkan berat total sudu dengan berat bahan serat karbon. Dari pengukuran berat yang dilakukan, diperoleh data seperti tabel 2.

Tabel 2. Berat benda uji (sudu)

Data hasil pengukuran berat bahan serat karbon, berat resin dan berat sudu dan juga diolah untuk mendapatkan perbandingan antara berat serat dan berat resin. Pengolahan data untuk mendapatkan perbandingan berat serat karbon dan berat resin terlihat pada tabel 2 di dua kolom terakhir. Data hasil perhitungan tersebut menunjukkan bahwa berat resin lebih dominan dibanding berat serat karbon, yaitu berada pada kisaran angka $71 \%$ sampai $74 \%$. Artinya bahwa resin SHCP memiliki peran yang besar dalam menyumbang sifat kekakuan (stiffness). Hal ini sejalan dengan sifat dasar resin SHCP yang memang bersifat keras dan getas 


\subsection{Karakeristik Mekanik Sudu Turbin Angin.}

Dari pengujian sudu turbin angin sumbu vertikal ini, ingin diperoleh angka kekuatan lentur dan kekakuan dari sudu turbin angin tersebut. Lebih jauh lagi, dengan memvariasikan tinggi tulang pada sudu, ingin diketahui juga besarnya pengaruh inersia penampang (yang diwakili dengan tinggi tulang) terhadap kekakuan sudu turbin angin, khususnya untuk sudu yang terbuat dari komposit serat karbon dan resin. Paramater yang langsung diperoleh dari pengujian adalah gaya (beban) yang diterapkan pada sudu dan besar defleksi pada ujung sudu. Besar angka beban dan defleksi yang tercantum dalam tabel 3 adalah angka beban dan defleksi maksimum yang terjadi sesaat sebelum sudu patah.

Tabel 3. Besar gaya (beban) dan defleksi maksimum pada sudu

\begin{tabular}{ccccc}
\hline No & Tinggi tulang sudu (mm) & $\begin{array}{c}\text { Nomor Benda uji } \\
(\mathbf{s u d u})\end{array}$ & $\begin{array}{c}\text { Gaya } \\
\mathbf{( k g )}\end{array}$ & $\begin{array}{c}\delta \\
(\mathbf{m m})\end{array}$ \\
\hline 1 & 6 & Benda uji 1 & 2.2 & 90 \\
\hline 2 & & Benda uji 2 & 2.4 & 80 \\
\hline 3 & & Benda uji 3 & 2.4 & 105 \\
\hline 1 & 9 & Benda uji 1 & 3.5 & 50 \\
\hline 2 & & Benda uji 2 & 3.4 & 50 \\
\cline { 2 - 5 } 3 & 12 & Benda uji 3 & 4.2 & 50 \\
\hline 1 & & Benda uji 1 & 6.0 & 20 \\
\hline 2 & & Benda uji 2 & 5.5 & 25 \\
\hline 3 & & Benda uji 3 & 6.5 & 35 \\
\hline
\end{tabular}

\section{Kekuatan Lentur Sudu}

Kekuatan lentur sudu turbin didapatkan dari perhitungan yang didasarkan dari hasil pengujian. Gaya (beban) yang digunakan untuk menghitung kekuatan lentur adalah beban rata-rata dari pengujian sudu turbin angin untuk masing-masing ukuran tinggi tulang. Kekuatan lentur sudu dihitung dengan persamaan :

$$
\sigma=\frac{M \times C}{I_{x x}}
$$

Dari perhitungan yang dilakukan, diperoleh rata-rata kekuatan lentur dari masing-masing sudu seperti yang terlihat pada tabel 4. Peningkatan kekuatan lentur sebagai efek dari penambahan tulang penguat juga diperlihatkan pada grafik kekuatan lentur maksimum pada gambar 10.

Tabel 4. Kekuatan lentur sudu

\begin{tabular}{ccccccc}
\hline No & $\begin{array}{c}\text { tinggi } \\
\text { tulangan } \\
(\mathbf{m m})\end{array}$ & $\begin{array}{c}\text { beban rata-rata } \\
\text { maksimum } \\
\mathbf{( k g )}\end{array}$ & $\begin{array}{c}\text { Lengan } \\
\text { momen } \\
\mathbf{( m m )}\end{array}$ & $\begin{array}{c}\mathbf{C} \\
(\mathbf{m m})\end{array}$ & $\begin{array}{c}\mathbf{I x x} \\
\left(\mathbf{m m}^{\mathbf{4}}\right)\end{array}$ & $\begin{array}{c}\sigma_{\text {max }} \\
\left(\mathbf{k g} / \mathbf{m m}^{\mathbf{2}}\right)\end{array}$ \\
\hline 1 & 6 & 2,3667 & 150 & 5,0000 & 442,91 & 4,008 \\
\hline 2 & 9 & 4,3000 & 150 & 7,5000 & 1004,23 & 4,145 \\
\hline 3 & 12 & 6,0000 & 150 & 10,1000 & 2000,45 & 4,544 \\
\hline
\end{tabular}




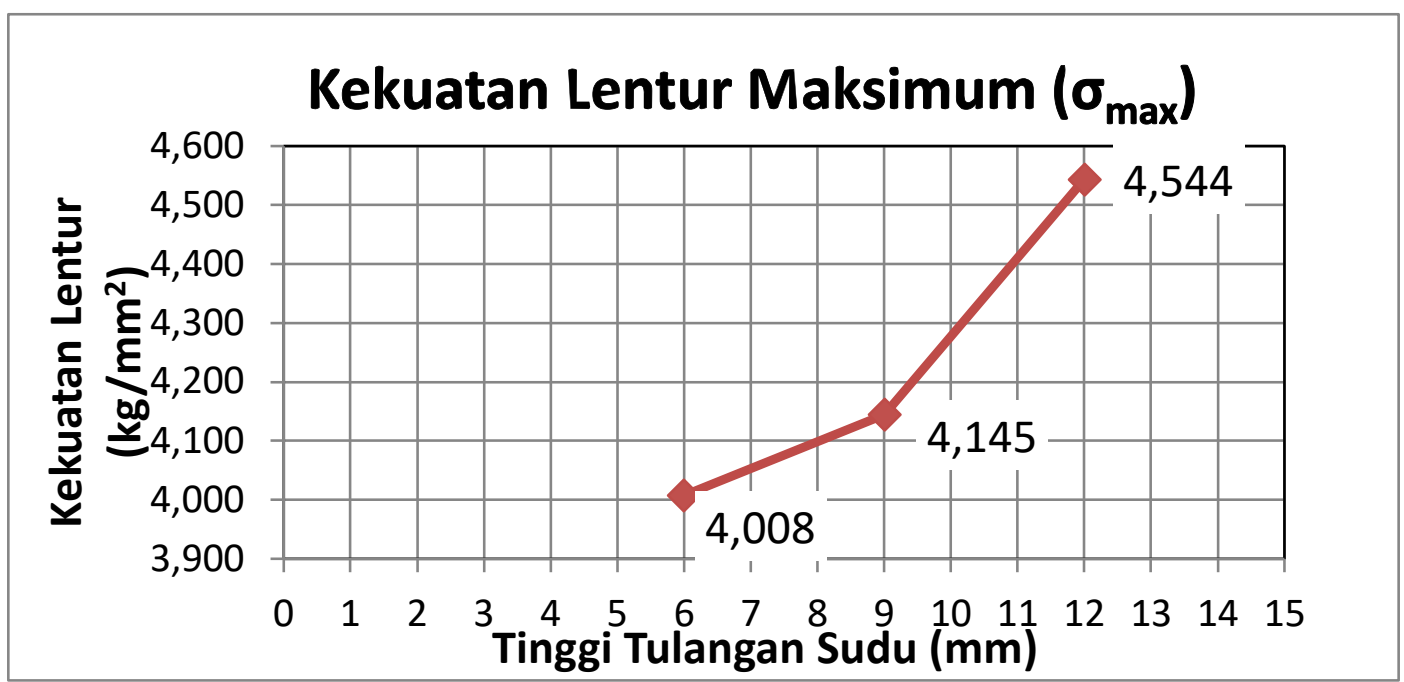

Gambar 10. Grafik kekuatan lentur sudu

Penambahan tulang rusuk penguat pada sudu turbin angin sumbu vertikal telah menambah kekuatan lentur sudu. Pengujian yang dilakukan pada sudu turbin angin sumbu vertikal dengan tambahan tulang penguat dengan tinggi tulang $6 \mathrm{~mm}, 9 \mathrm{~mm}$ dan $12 \mathrm{~mm}$ menunjukkan peningkatan kekuatan yang cenderung mengikuti fungsi eksponensial. Hal ini sejalan dengan persamaan inersia penampang dari bentuk persegi yang setara dengan pangkat 3 dari tinggi penampang persegi.

\section{Kekakuan Sudu}

Kekakuan sudu turbin didapatkan dari perhitungan yang didasarkan dari hasil pengujian.. Gaya (beban) yang digunakan untuk menghitung kekakuan adalah beban rata-rata dari pengujian sudu turbin angin untuk masing-masing ukuran tinggi tulang. Kekakuan sudu dihitung dengan persamaan :

$$
K=\frac{P}{\delta}=\frac{6 E I}{a^{2}(3 L-a)}
$$

Dari perhitungan yang dilakukan, diperoleh hasil kekakuan sudu seperti yang terlihat pada tabel 5 Peningkatan kekakuan sudu sebagai efek dari penambahan tulang penguat juga diperlihatkan pada grafik kekakuan pada gambar 11 .

Tabel 5. Defleksi dan angka kekakuan

\begin{tabular}{ccccc}
\hline No & $\begin{array}{c}\text { tinggi tulang } \\
(\mathbf{m m})\end{array}$ & $\begin{array}{c}\text { Beban (gaya) rata-rata } \\
\mathbf{( k g )}\end{array}$ & $\begin{array}{c}\text { Srata-rata } \\
(\mathbf{m m})\end{array}$ & $\begin{array}{c}\text { Kekakuan } \\
\mathbf{( K g / m m})\end{array}$ \\
\hline 1 & 6 & 2,3667 & 91,667 & 0,0258 \\
\hline 2 & 9 & 3,7000 & 50,000 & 0,0740 \\
\hline 3 & 12 & 6,0000 & 26,667 & 0,2250 \\
\hline
\end{tabular}




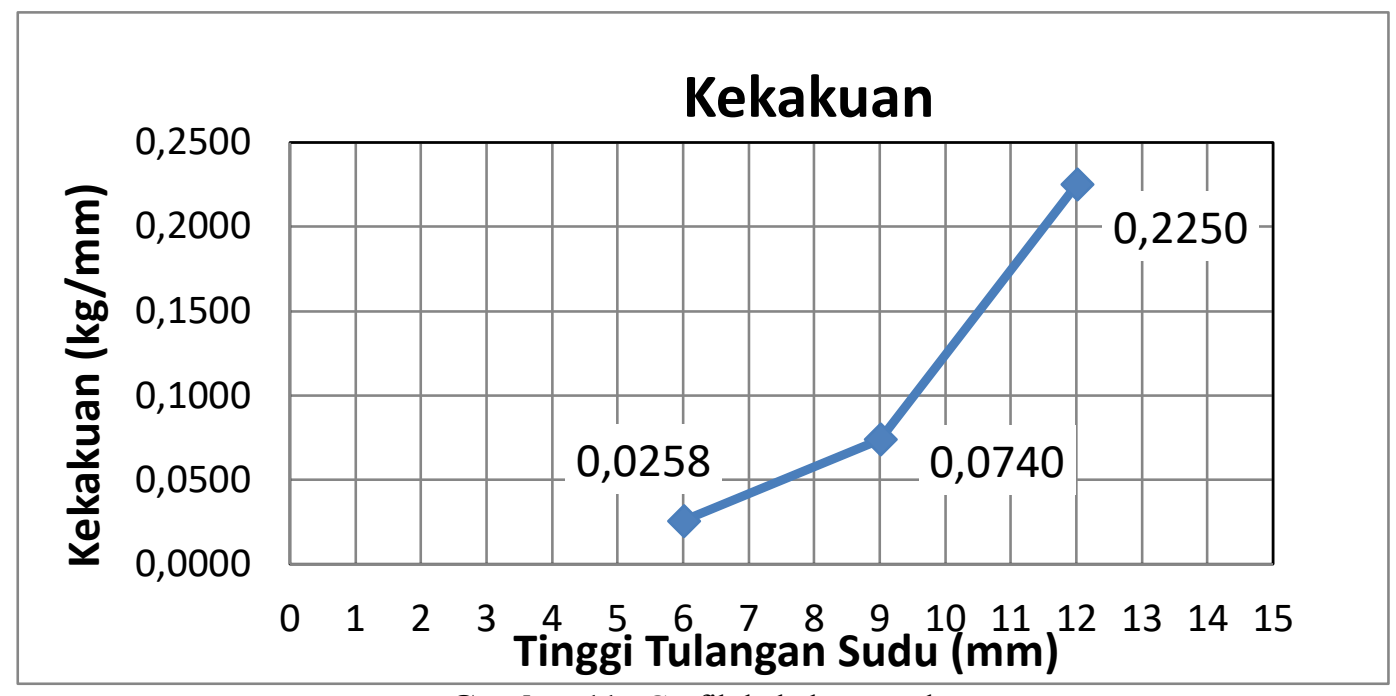

Gambar 11. Grafik kekakuan sudu

Penambahan tulang rusuk penguat pada sudu turbin angin sumbu vertikal telah menambah kekakuan sudu secara signifikan. Sudu turbin angin yang pada awalnya dibuat dari bahan komposit serat karbon satu layer dan resin SHCP tanpa tulang dapat dikatakan tidak memiliki kekakuan. Tapi setelah diberi tambahan tulang dari bahan komposit yang sama, kekakuannya meningkat. Pengujian yang dilakukan pada sudu turbin angin sumbu vertikal dengan tambahan tulang penguat dengan tinggi tulang $6 \mathrm{~mm}$, $9 \mathrm{~mm}$ dan $12 \mathrm{~mm}$ menunjukkan peningkatan kekuatan yang cenderung mengikuti fungsi eksponensial. Hal ini sejalan dengan persamaan inersia penampang dari bentuk persegi yang setara dengan pangkat 3 dari tinggi persegi.

Tabel 6. perbandingan penambahan berat sudu terhadap peningkatan kekuatan lentur dan peningkatan kekakuan

\begin{tabular}{cccccccc}
\hline No & $\begin{array}{c}\text { Tinggi } \\
\text { tulang } \\
(\mathrm{mm})\end{array}$ & $\begin{array}{c}\text { berat sudu } \\
\text { rata-rata } \\
(\mathrm{gram})\end{array}$ & $\begin{array}{c}\sigma_{\mathrm{max}} \\
\left(\mathrm{kg} / \mathrm{mm}^{2}\right)\end{array}$ & $\begin{array}{c}\text { Kekakuan } \\
(\mathrm{kg} / \mathrm{mm})\end{array}$ & $\begin{array}{c}\text { Penambahan } \\
\text { berat }\end{array}$ & $\begin{array}{c}\text { Peningkatan } \\
\text { kekuatan }\end{array}$ & $\begin{array}{c}\text { Peninkgatan } \\
\text { kekakuan }\end{array}$ \\
\hline 1 & 6 & 121,00 & 4,008 & $\mathbf{0 , 0 2 5 8}$ & - & - & - \\
\hline 2 & 9 & 125,00 & 4,145 & $\mathbf{0 , 0 7 4 0}$ & $3 \%$ & $3 \%$ & $187 \%$ \\
\hline 3 & 12 & 126,67 & 4,544 & $\mathbf{0 , 2 2 5 0}$ & $1 \%$ & $\mathbf{1 0 \%}$ & $204 \%$ \\
\hline
\end{tabular}

Perbedaan berat di antara 3 sudu dengan tinggi tulang $6 \mathrm{~mm}, 9 \mathrm{~mm}$ dan $12 \mathrm{~mm}$ hanya terpaut sedikit, kira-kira 4 gram dan 1 gram. Tetapi selisih yang hanya sedikit ini telah memberikan peningkatan kekakuan dan kekuatan yang signifikan, seperti yang terlihat pada tabel 6 .

Gaya drag teoritik akibat kecepatan angin sebesar $5 \mathrm{~m} / \mathrm{s}$ yang bekerja pada penampang sudu turbin dengan dimensi radius $150 \mathrm{~mm}$ dan tinggi $250 \mathrm{~mm}$ adalah sebesar 2,5875 N. Untuk menjaga agar sudu turbin angin tidak terdefleksi secara berlebihan, maka tinggi tulang penguat yang sesuai untuk beban tersebut dapat ditentukan dengan cara menghitung defleksi yang terjadi pada sudu, yaitu dengan membagi beban dengan angka kekakuan sudu. Perhitungan defleksi yang terjadi pada masing-masing sudu dengan variasi tinggi tulang penguat terlihat pada tabel 7 . 
Tabel 7. Perhitungan defleksi pada sudu turbin dengan beban (gaya drag) pada kecepatan angin $5 \mathrm{~m} / \mathrm{s}$ dengan tinggi tulang penguat $6,9,12 \mathrm{~mm}$

\begin{tabular}{cccccc}
\hline \multirow{2}{*}{ No } & $\begin{array}{c}\text { Tinggi tulang } \\
(\mathbf{m m})\end{array}$ & $\begin{array}{c}\text { Kekakuan } \\
\mathbf{( k g / m m})\end{array}$ & \multicolumn{2}{c}{ Beban (gaya drag) } & \multirow{2}{*}{ Defleksi (mm) } \\
\cline { 4 - 5 } & 6 & 0,0258 & 2,59 & $\mathbf{( k g )}$ & \\
\hline 2 & 9 & 0,0740 & 2,59 & 0,26 & 10,23 \\
\hline 3 & 12 & 0,2250 & 2,59 & 0,26 & 3,57 \\
\hline
\end{tabular}

Dengan asumsi bahwa defleksi sebesar 5mm pada ujung sudu turbin tidak akan menurunkan kinerja sudu turbin, maka hasil perhitungan defleksi sudu turbin yang terlihat pada tabel 7 menunjukkan bahwa sudu turbin angin sudah mencapai kekakuan yang cukup dengan tinggi tulang $9 \mathrm{~mm}$

\section{SIMPULAN}

Penambahan tulang rusuk penguat (stifferner rib) pada sudu turbin angin sumbu vertikal telah menambah kekakuan dan kekuatan lentur sudu secara signifikan dan cenderung mengikuti fungsi eksponensial. Kekuatan lentur maksismum $\left(\sigma_{\max }\right)$ sudu dengan tinggi tulang $6 \mathrm{~mm}$ adalah 4,008 $\mathrm{kg} / \mathrm{mm}^{2}$. Kekuatan lentur maksismum $\left(\sigma_{\max }\right)$ sudu dengan tinggi tulang $9 \mathrm{~mm}$ adalah $4,145 \mathrm{~kg} / \mathrm{mm}^{2}$. Kekuatan lentur maksismum $\left(\sigma_{\max }\right)$ sudu dengan tinggi tulang $12 \mathrm{~mm}$ adalah 4,544 kg/mm ${ }^{2} \mathrm{Kekakuan}$ (K) sudu dengan tinggi tulang $6 \mathrm{~mm}$ adalah $0,0258 \mathrm{~kg} / \mathrm{mm}$. Kekakuan $(\mathrm{K})$ sudu dengan tinggi tulang 9 $\mathrm{mm}$ adalah $0,0740 \mathrm{~kg} / \mathrm{mm}$. Kekakuan $(\mathrm{K})$ sudu dengan tinggi tulang $12 \mathrm{~mm}$ adalah $0,2250 \mathrm{~kg} / \mathrm{mm}$. Berdasarkan pengujian dan perhitungan yang telah dilakukan pada penelitian ini, kekakuan yang diinginkan pada sudu turbin angin sumbu vertikal dengan ukuran radius sudu $150 \mathrm{~mm}$, tinggi $250 \mathrm{~mm}$, pada kecepatan angin $5 \mathrm{~m} / \mathrm{s}$ dapat dicapai dengan penambahan tulang penguat dengan lebar tulang 30 $\mathrm{mm}$ dan tinggi tulang $9 \mathrm{~mm}$.

\section{DAFTAR PUSTAKA}

[1] S. Jagadish Venkata Sai, T. Venkateswara Rao (2016), "Design and Analysis of Vertical Axis Savonius Wind Turbine", International Journal of Engineering and Technology (IJET), e-ISSN : 0975-4024, p-ISSN : 2319-8613, Vol 8 No 2 Apr-May 2016, pp- 1069- 1076

[2] Hero P.Dida, Sudjito Suparman, Denny Widhiyanuriyawan (2016), "Pemetaan Potensi Energi Angin di Perairan Indonesia Berdasarkan Data Satelit QuikScat dan WindSat”, Jurnal Rekayasa Mesin ISSN: 2477-6041, Vol.7, No.2 Tahun 2016: pp-95-101

[3] Mohammed Hadi Ali (2013) "Experimental Comparison Study for Savonius Wind Turbine of Two \& Three Blades At Low Wind Speed", International Journal of Modern Engineering Research (IJMER), ISSN: 2249-6645, Vol. 3, Issue. 5, Sep - Oct. 2013 pp-2978-2986,

[4] James L. Tangler (2000), "The Evolution of Rotor and Blade Design" Conference of American Wind Energy Association Wind Power 2000, Palm Springs, California, April 30 - May 4, 2000

[5] Anonim (2001) IEC-TS 61400-23 Wind turbine generator systems - Part 23: Full-scale Structural Testing of Rotor Blades. 